\title{
Extended Antiphospholipid Antibodies Screening in Systemic Lupus Erythematosus Patients
}

\author{
ALINA DIMA $^{1,2}$, SIMONA CARAIOLA $^{1,2}$, C. JURCUT ${ }^{3}$, EUGENIA BALANESCU $^{2}$, P. BALANESCU ${ }^{1,2}$, DOINA RAMBA $^{1,2}$,

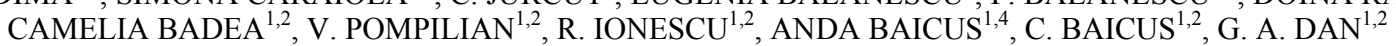 \\ l" "Carol Davila" University of Medicine and Pharmacy, Bucharest \\ "“Colentina" Research Center, Colentina Clinical Hospital, Bucharest \\ 3“Dr. Carol Davila" Central University Emergency Military Hospital, Bucharest \\ 4“Cantacuzino" National Institute of Research and Development in Microbiology-Immunology, Bucharest, Romania
}

\begin{abstract}
Background. The antiphospholipid syndrome (APS) is one of the most encountered autoimmunity in systemic lupus erythematosus (SLE) patients and pathogenesis of these two seems to be intricate.

Aim. To investigate the association of antiphospholipid antibodies (APLAs) titer with the presence of secondary APS diagnosis in SLE patients.

Methods. 65 patients fulfilling the 2012 Systemic Lupus Collaborating International Clinics (SLICC) SLE's criteria were included. The APS diagnosis was sustained according to the 2006 Sydney APS's criteria. Three groups of patients were defined: SLE patients with secondary APS, SLE with history of positive "criteria" APLAs but without APS clinical features, respectively SLE patients without positive APLAs or clinical APS criteria. An extended APLAs panel was searched in all cases: both IgM and IgG of anticardiolipin antibodies (aCL), anti- $\beta 2$ glycoprotein I antibodies (aß2GPI), antiphosphatidylethanolamine antibodies (aPE), antiphosphatidylserine antibodies (aPS), respectively antiprothrombin antibodies (aPT).

Results. Only the aß2GPI, both IgM and IgG serotypes, had significantly higher titers in patients with SLE and secondary APS compared to no APS (with/ without positive APLAs): median $(\min ; \max ) 7.0(0.0-300.0)$ vs. $1.0(0.0-28.0)$ vs. $1.0(0.0-12.0)$, respectively $3.0(0.0-79.0)$ vs. 1.0 $(0.0-3.0)$ vs. $1.0(0.0-12.0)(\mathrm{p}<0.001$, Kruskal-Wallis test $)]$. Also, in regression logistic models, only the aß2 GPI (IgG and IgM ) were identified as risk factors for secondary APS diagnosis in the SLE patients: OR(95\%CI) $5.9(2.2-15.7)$, respectively $1.3(1.1-1.5)$. In regard with the SLE markers, the IgG serotypes of the "non-criteria" APLAs analyzed (aPS, aPT, aPE) were correlated with the antiDNA titers while the IgM serotypes inversely associated with the complement $\mathrm{C} 3$ levels.

Conclusions. IgG a 2 GPI are accompanied by almost 6-fold increase risk of secondary APS when screening SLE patients. On the contrary, the "non-criteria" APLAs do not seem associated with the APS diagnosis in SLE patients. Some correlates of the "non-criteria" APLAs with the antiDNA and complement $\mathrm{C} 3$ levels were also observed.
\end{abstract}

Key words: Anti- $\beta 2$ glycoprotein I antibodies, antiphosphatidylethanolamine; antiprothrombine; antiphosphatidylserine; systemic lupus erythematosus; antiphospholipid syndrome.

\section{INTRODUCTION}

The "criteria" antiphospholipid antibodies (APLAs) - lupus anticoagulant (LAC), anticardiolipin antibodies $(\mathrm{aCL})$ and anti- $\beta 2$ glycoprotein I antibodies (aß2GPI) - are part of both 2012 Systemic Lupus Collaborating International Clinics revised and validated by the American College of Rheumatology (SLICC/ACR) systemic lupus erythematosus (SLE) [1] and 2006 Sydney APS diagnostic criteria [2].

Furthermore, the APLAs are some of the most frequent antibodies encountered in SLE patients, positive in 30 to $40 \%$ of the SLE patients. Among the "criteria" APLAs, the aCL are the most common encountered in SLE patients, $47 \%$, followed by the
aß2GPI and LAC, $33 \%$ and $26 \%$, respectively [3]. Even so, only one third of these patients will have APS, suggesting that the APLAs positivity is not the only pathogenic link [4]. The APLAs tend to precede the clinical APS events by several years and their positivity characterized a subset of the SLE disease with early disease and severe outcome [5]. Among the APS patients, one third [6] to 45\% [7] are secondary to the SLE or have SLE-like disease. These data suggested that the occurrence of both APS and SLE might have common determinants [8] and that the APLAs production might be genetically determined [9].

Apart of diagnostic APLAs, there are also "non-criteria" APLAs, like antiphosphatidylethanolamine antibodies (aPE), antiphosphatidylserine 
antibodies (aPS), antiprothrombin antibodies (aPT) or anti-prothrombin in complex with phosphatidylserine antibodies (aPS/PT) that have similar phospholipidic structure with the "criteria" APLAs, but for which the clinical significance remains still uncertain.

In this research, we realized an extended screening for "criteria" and "non-criteria" APLAs in SLE patients, with or without secondary APS, in order to investigate their relevance for the secondary APS diagnostic, as well as the association with the SLE biologic parameters.

\section{METHODS}

\section{Subjects' description}

Patients fulfilling the 2012 SLICC/ACR SLE's criteria [1] were included. The diagnosis of secondary APS was noted according to the 2006 Sydney APS's criteria [2]. The presence of acute or chronic infections, as well as the overlap syndrome with another connective tissue disease were considered exclusion criteria.

Data regarding the history of any diagnosis criteria of both SLE and APS were collected in all patients. Values of the serum anti-DNA, respectively complement $\mathrm{C} 3$ and $\mathrm{C} 4$ levels, were noted when present in the patients' files at inclusion.

\section{Groups of patients}

After analyzing the antecedents of APS's clinical diagnosis criteria (thrombotic events or pregnancy pathology) as well as those related to the previous APLAs determinations, three groups of patients were defined:

Group 1 - SLE patients with secondary APS (presence of previous thrombotic events or pregnancy pathology and twice or more positive determinations of at least one of the diagnostic APLAs: LAC, aCL or aß2GPI).

Group 2 - SLE patients without APS's clinical criteria (without previous thrombotic events or pregnancy pathology), but with previous positive APLAs determinations (previous positive results for the LAC, aCL or aß2GPI; these data were obtained from the patients' files).

Group 3 - SLE patients without APS's clinical criteria (without previous thrombotic events or pregnancy pathology) and without antecedents of positive APLAs (only negative previous determinations of LAC, $\mathrm{aCL}$ or a $\beta 2 \mathrm{GPI}$ )

\section{APLAs determination}

Blood samples were collected at inclusion in all patients; these were centrifuged 15 minutes at $4000 \mathrm{rpm}$ and then stored frozen at $-70^{\circ}$ in the Immunology Laboratory of Colentina Research Center.

Extended APLAs profile was searched in all cases: IgG and IgM aCL, IgG and IgM aß2GPI, $\mathrm{IgG}$ and $\operatorname{IgM}$ aPS, IgG and IgM aPE, respectively IgG and IgM aPT.

All determinations were made by ELISA Aesku Diagnostics, Wendelsheim, Germany using the analyzer Chemwell 2910, Awareness Technology, Palm City, Florida, USA. For each sample, mean optical density at $450 \mathrm{~nm}$ was considered (BioRad Hercules, CA, SUA).

\section{Statistical analysis}

The cases characteristics were summarized as mean \pm standard deviation for normally distributed variables and as median (minimum; maximum) for those with non-Gaussian distribution. Nonparametric correlation was computed (Kendall's tau coefficient). The differences of the APLAs titers between the three groups defined in our study were analyzed by the Kruskal-Wallis test and the differences between the groups two-by-two were further analyzed, with the utilization of the posttest corrections (Bonferroni). The proportion of the total variance in a dependent variable was assessed by etasquared (chi-squared obtained by Kruskal-Wallis test divided to "n-1"). Multivariate analysis by logistic regression was realized for determining the APLAs titers as predictors for the secondary APS diagnosis. Each time the logistic regression model included the following variable: gender, age at inclusion, SLE disease duration, anti-DNA and complement C3 levels as well as the titer of the respective APLAs considered into analysis. Odds ratios (ORs) and 95\% confidence intervals (CIs) were also calculated. Two-sided p-values less than 0.05 were considered statistically significant. In all analysis, SPSS version 16.0 (Chicago, IL, USA) was used.

\section{RESULTS}

\section{Subjects descriptions on the three groups}

Data of 28 patients with SLE and secondary APS (Group 1), 8 patients with previous positive APLAs but without antecedents of thrombotic events 
or pregnancy pathology (Group 2), respectively 29 SLE patients without history of positive APLAs (Group 3) were taken into analysis (see Table 1).

Both ages at inclusion in the study as well as the SLE disease duration were higher among the patients with SLE and secondary APS than in those only with history of positive APLAs but without clinical APS criteria. The lowest age at inclusion and disease duration were observed in patients with SLE without any biological or clinical features of APS - the patients with SLE and secondary APS had mean (SD) age at inclusion of 45.5 (11.2) and 11.5 years of disease duration, substantially higher than that of the SLE patients with negative APS characteristics, mean (SD) age at inclusion of 41.8 (13.2), respectively 4.0 years disease duration.

Table 1

Subjects description (Group 1 - SLE patients with secondary APS, Group 2 - SLE patients with positive APLAs but without APS's clinical criteria, Group 3 - SLE patients without positive APLAs)

\begin{tabular}{llll}
\hline Characteristic & Group 1 & Group 2 & Group 3 \\
\hline Number & 28 & 8 & 29 \\
Gender, F/M (\%F) & $27 / 1(96.4)$ & $4 / 4(50.0)$ & $27 / 2(93.1)$ \\
Age at inclusion, years* & $45.5 \pm 11.2$ & $43.2 \pm 14.3$ & $41.8 \pm 13.2$ \\
SLE's diagnosis age, years* & $33.7 \pm 9.3$ & $31.4 \pm 15.3$ & $36.9 \pm 14.2$ \\
Disease duration, years** & $11.5(0.3 ; 32.0)$ & $6.5(0.1 ; 20.0)$ & $4.0(0.5 ; 18.0)$ \\
Anti-DNA titer, UI/mL** & $98.7(6.5-1153.8)$ & $42.8(9.7-1615.0)$ & $100.0(9.2-1194.4)$ \\
Complement C3, g/L** & $1.1(0.4 ; 1.8)$ & $1.1(0.3 ; 1.3)$ & $0.9(0.3 ; 1.5)$ \\
Complement C4, g/L** & $0.2(0.0 ; 0.4)$ & $0.2(0.0 ; 0.3)$ & $0.2(0.0 ; 0.4)$ \\
\hline
\end{tabular}

$*$ mean $\pm \mathrm{SD}$

**median (min; max)

\section{Extended APLAs panel in the three groups of patients}

We found significantly higher APLAs titers in first group of patients (SLE with secondary APS) when compared with the other SLE patients, both groups 2 or 3, only for two APLAs: a $32 \mathrm{GPI}$ IgM and IgG [median (min; max) 7.0 (0.0-300.0) vs. $1.0(0.0-28.0)$ vs. $1.0(0.0-12.0) ; \mathrm{p}<0.001$, respectively $3.0(0.0-79.0)$ vs. $1.0(0.0-3.0)$ vs. 1.0 $(0.0-12.0) ; \mathrm{p}<0.001]$.

Other four antibodies were found to have significantly higher titers in patients with SLE and secondary APS (group 1) than in patients with SLE and negative previous APLAs (group 3): IgM aCL, IgM aPS, IgG aPS, respectively IgG aPE (see Table 2).

Table 2

The APLAs titers in the three groups of patients (Group 1 - SLE patients with secondary APS,

Group 2 - SLE patients with positive APLAs but without APS's clinical criteria, Group 3 - SLE patients without positive APLAs)

\begin{tabular}{|c|c|c|c|c|c|c|c|c|}
\hline Characteristic & Group 1 & $\mathrm{UI} / \mathrm{mL} ; \operatorname{med}(\min ; \max )$ & $\begin{array}{l}\text { Group } 3 \\
\text { x) }\end{array}$ & p* & $\eta^{2 * *}$ & $\mathrm{p}(1 / 2)^{* * *}$ & $\mathrm{p}(2 / 3) * * *$ & $\mathrm{p}(1 / 3)^{* * *}$ \\
\hline IgM aCL & $4.0(0.0-41.0)$ & $1.0(0.0-29.0)$ & $2.0(0.0-69.0)$ & .004 & .174 & NS & NS & $<.001$ \\
\hline IgG aCL & $1.0(0.0-64.0)$ & $2.0(1.0-28.0)$ & $2.0(0.0-23.0)$ & .148 & .597 & NS & NS & NS \\
\hline IgM a $\beta 2$ GP I & $7.0(0.0-300.0)$ & $1.0(0.0-28.0)$ & $1.0(0.0-12.0)$ & .000 & .307 & .036 & NS & $<.001$ \\
\hline IgG a $\beta 2$ GP I & $3.0(0.0-79.0)$ & $1.0(0.0-3.0)$ & $1.0(0.0-2.0)$ & .000 & .523 & .006 & NS & $<.001$ \\
\hline IgM aPT & $4.0(0.0-13.0)$ & $2.0(0.0-26.0)$ & $2.0(0.0-143.0)$ & .301 & .375 & NS & NS & NS \\
\hline IgG aPT & $3.5(0.0-20.0)$ & $4.0(2.0-19.0)$ & $4.0(2.0-82.0)$ & .744 & 0.09 & NS & NS & NS \\
\hline IgM aPS & $4.5(0.0-31.0)$ & $1.0(0.0-28.0)$ & $1.0(0.0-73.0)$ & .001 & .222 & NS & NS & $<.001$ \\
\hline IgG aPS & $2.0(1.0-112.0)$ & $1.0(1.0-14.0)$ & $1.0(1.0-9.0)$ & .019 & .124 & NS & NS & .012 \\
\hline IgM aPE & $7.0(0.0-202.0)$ & $2.0(1.0-82.0)$ & $3.0(1.0-26.0)$ & 005 & .164 & NS & NS & .006 \\
\hline IgG aPE & $3.0(1.0-151.0)$ & $3.0(1.0-56.0)$ & $2.0(1.0-22.0)$ & .746 & .009 & NS & NS & NS \\
\hline
\end{tabular}

$\mathrm{p}$ - significant value $<0.05, \mathrm{NS}-$ non-significant

*Kruskal-Wallis test, **Eta squared; ***with Bonferroni correction applied

\section{Univariate analysis}

Statistically significant correlations, but associated with low strength of association as expressed by the Kendall's tau coefficient, were found between the anti-DNA titer and those of theIgG aCL, IgG aPE, respectively IgG aPT anti- bodies. Moreover, the complement C3 levels were indirectly correlated with the IgM aCL, IgM aPE, IgM aPS, respectively IgM and IgG aPT titers, while the complement $\mathrm{C} 4$ levels were significantly negatively correlated only with both $\operatorname{IgM}$ and $\operatorname{IgG}$ aPT titers (see Table 3). 


\section{Multivariate analysis}

In regression logistic models adjusted for sex, age, disease duration, anti-DNA titer and complement C3 levels, only the IgG and IgM aß2 GPI were associated with increased risk of secondary APS in SLE patients. The highest relative risk of secondary APS seems to be associated to the $\operatorname{IgG}$ a 32 GPI, almost 6-fold increase (as presented in Table 4).

Table 3

The correlations of antiDNA antibodies with the APLAs

\begin{tabular}{|c|c|c|c|c|c|c|c|c|c|c|}
\hline & $\operatorname{IgM} \mathbf{a C L}$ & IgG aCL & $\begin{array}{c}\operatorname{IgM} \\
\text { aß2GPI }\end{array}$ & $\begin{array}{c}\mathrm{IgG} \\
\mathbf{a \beta 2 G P I}\end{array}$ & $\begin{array}{l}\text { IgM } \\
\text { aPE }\end{array}$ & $\begin{array}{c}\text { IgG } \\
\text { aPE }\end{array}$ & $\begin{array}{l}\text { IgM } \\
\text { aPS }\end{array}$ & $\begin{array}{l}\operatorname{IgG} \\
\text { aPS }\end{array}$ & $\begin{array}{l}\text { IgM } \\
\text { aPT }\end{array}$ & $\begin{array}{c}\text { IgG } \\
\text { aPT }\end{array}$ \\
\hline $\begin{array}{c}\text { antiDNA } \\
\mathrm{n}=57\end{array}$ & NS & $\begin{array}{l}\mathrm{p}=\mathbf{. 0 0 3} \\
\mathrm{r}=.271\end{array}$ & NS & NS & NS & $\begin{array}{l}\mathrm{p}=\mathbf{. 0 4 8} \\
\mathrm{r}=.180\end{array}$ & NS & $\begin{array}{l}\mathrm{p}=\mathbf{. 0 0 5} \\
\mathrm{r}=.260\end{array}$ & NS & $\begin{array}{l}\mathrm{p}=\mathbf{. 0 1 6} \\
\mathrm{r}=.221\end{array}$ \\
\hline $\begin{array}{c}\mathbf{C 3} \\
\mathrm{n}=61\end{array}$ & $\begin{array}{l}\mathrm{p}=\mathbf{. 0 0 4} \\
\mathrm{r}=-.255\end{array}$ & $\mathrm{NS}$ & NS & NS & $\begin{array}{l}\mathrm{p}=\mathbf{. 0 0 7} \\
\mathrm{r}=-.240\end{array}$ & $\mathrm{NS}$ & $\begin{array}{l}\mathrm{p}=\mathbf{. 0 0 8} \\
\mathrm{r}=-.237\end{array}$ & $\mathrm{NS}$ & $\begin{array}{l}\mathrm{p}=\mathbf{. 0 0 1} \\
\mathrm{r}=-.307\end{array}$ & $\begin{array}{l}\mathrm{p}=\mathbf{. 0 1 2} \\
\mathrm{r}=-.226\end{array}$ \\
\hline $\begin{array}{c}\text { C4 } \\
\mathrm{n}=60\end{array}$ & NS & NS & NS & NS & NS & NS & NS & NS & $\begin{array}{l}\mathrm{p}=\mathbf{. 0 3 5} \\
\mathrm{r}=-.193\end{array}$ & $\begin{array}{l}\mathrm{p}=\mathbf{. 0 0 3} \\
\mathrm{r}=-.273\end{array}$ \\
\hline
\end{tabular}

Table 4

APLA's titers as predictors for the APS's diagnosis by regression logistic by enter method (variables included into regression model: gender, age at inclusion, disease duration, anti-DNA, complement $\mathrm{C} 3$ and each time the specific APLA analyzed)

\begin{tabular}{llll}
\hline & p-value & OR (odds ratio) & CI (inf - sup) \\
\cline { 2 - 3 } IgG aCL & .467 & 1.032 & $0.949-1.112$ \\
IgM aCL & .060 & 1.163 & $0.994-1.361$ \\
IgG aß2 GP I & $\mathbf{. 0 0 0}$ & $\mathbf{5 . 9 3 6}$ & $2.240-15.733$ \\
IgM aß2 GP I & $\mathbf{. 0 1 1}$ & $\mathbf{1 . 2 7 3}$ & $1.056-1.534$ \\
IgG aPE & .689 & 1.010 & $0.962-1.061$ \\
IgM aPE & .258 & 1.025 & $0.982-1.069$ \\
IgG aPS & .139 & 1.150 & $0.956-1.384$ \\
IgM aPS & .118 & 1.136 & $0.968-1.332$ \\
IgG aPT & .671 & 0.970 & $0.843-1.116$ \\
IgM aPT & .393 & 1.065 & $0.922-1.230$ \\
\hline p - significant value $<0.05$ & &
\end{tabular}

\section{DISCUSSION}

Both SLE and APS pathologies affect mainly young patients. The mean age at SLE diagnosis as well as that of the SLE population is less than 40 years old $[10,11], 33$ years [10], respectively 35 years [11] in some studies. For the APS, the mean age of occurrence is 33 years [6] and the mean age of the study population around 37 years [7]. Moreover, the SLE patients with positive APLAs tend to have early disease onset as well as more severe disease outcome [5]. In our research, the patients with SLE alone when compared to those with SLE and secondary APS had higher SLE's onset age and almost three times longer median SLE's disease duration suggesting the development of the APS in the middle of the SLE immune processes.

Some of the literature data described possible links between APS and SLE. In this regard, it was observed that the prevalence of "non-criteria" APLAs is higher in patients with SLE and secondary APS when compared with SLE without APS's features and their presence seems to increase the risk of thrombotic events [12].

In APS, clinical "non-criteria" APS manifestations, like superficial vein thrombosis, thrombocytopenia, renal microangiopathy, heart valve disease, livedo reticularis, migraine, chorea, seizures or myelitis [13], as well as "non-criteria" APLAs are described. The IgM aPS are more frequently encountered in the SLE patients than in healthy controls and might be correlated with the thrombotic events occurrence [14], or myocardial infarction [15]. The aPS in complex with aPT (aPT/PS complex) are present especially in SLE patients with serum LAC activity [16]. In the aPT and aPT/aPS complex, even different antibodies have partially an identical structure [17]. Analyzing the compounds of the global APS score, the IgG aPS/PT-a component was significantly associated with thrombosis [18]. Also, the aPS/PT might be taken in discussion for inclusion into the "criteria" APLAs [19]. Even if aPE are higher in SLE [14] 
and in APS patients [20] than in controls, their titers are not correlated with other APLAs [20]. There are studies that have not found any correlations of the aPE with the clinical APS events [20], but other authors sustained a possible utility in seronegative APS [21].

Searching the pathogenic links between SLE and APS, we analyzed here the correlations of the APLAs titers with the classic biologic markers used to follow-up the SLE patients. For the "noncriteria" APLAs, we found significant correlations for both anti-DNA and complement C3 levels only with the IgG aPT. The anti-DNA correlated also with the IgG serotypes of aPE and aPS. The complement $\mathrm{C} 3$, consumed during the immunological processes, was indirectly correlated with the IgM serotypes of aPE, aPS and aPT. Furthermore, among the "non-criteria" APLAs, significant higher titers in SLE with secondary APS when compared with SLE alone are present for aPS and IgM aPE, no significant difference was observed for aPT or IgG aPE.

In regard with the "criteria" APLAs, the LAC was the first described, found to be associated with 6-fold increase of the thrombotic risk [22]. The LAC does not recognize the phospholipids alone [23]; its activity seems to depend on the $\beta 2 \mathrm{GPI}$ presence [24] and so, it was observed the APS phenotype is not expressed when the 32 GPI expression is deficient [25]. The aCL positivity carries a 2-fold increase of venous thrombosis in SLE patients [22]. Apparently, the aCL are not expressed in patients with negative a $\beta 2$ GPI [26]. Also, some of the aCL has LAC activity, respectively those $\beta 2$ GPI dependent, but it is still unclear why only some aCL possess LAC activity [27].

Lately, there are data showing that $\beta 2 \mathrm{GPI}$ is necessary for the antibody with antiphospholipids interaction [28]. For this, the $\beta 2$ GPI interacts with annexins, a family of phospholipid-binding proteins, of which annexin A2 and A5 are involved in APD pathogenesis [29]. Moreover, the pathogenic APLAs seem not to be actually directed against phospholipids, but against the $\beta 2$ GPI [25]. From the $\beta 2 \mathrm{GPI}$, the epitope Gly40-Arg43 seem involved in inducing LAC activity and so with the increased thrombosis risk [30].

In this cross-sectional study, even we screened a large number of APLAs, one of the limitations was that we did not have any data on the LAC presence at the moment of the patients inclusion.

In our research, both IgM and IgG a 32 GPI titers were significantly higher in SLE patients that experienced APS's clinical events than in any of the other two SLE groups, suggesting their involvement in the APS's clinical expression. We did not find similar results for the other "criteria" APLAs tested, meaning IgG or IgM aCL. Also, the IgG a 32 GPI associated an almost 6-fold and the IgM aß2GPI a 1.3-fold increased risk of secondary APS presence in SLE patients.

The presence of the APS pro-coagulant phenotype in patients with positive APLAs is not completely understood and might be related to other factors than APLAs also [29]. The APLAs positivity is not necessarily related to the APS's clinical events, only $8.1 \%$ of the patients with positive APLAs will develop a first thrombotic event in 5 years follow-up period [31]. The presence of SLE itself might play a role in thrombosis development as the risk of APS's clinical manifestation is greater in SLE with secondary APS than in primary APS [32]. Other factors than the APLAs positivity were also identified as independent risk factors for APS's clinical events in APS patients, like hypertension [31,32], hypertriglyceridemia [32], diabetes [33], poverty, higher glucocorticoids doses or damage accrual [34].

\section{CONCLUSIONS}

Regarding the possible pathogenic links between the SLE and APS development, we observed that the IgG serotypes of the "non-criteria" APLAs are significantly associated with the antiDNA production while the IgM serotypes with the complement C3 consumption.

The aß2GPI antibodies seem to be the most reliable APLAs for identification of secondary APS when an extended APLAs screening is applied in SLE patients, the IgG aß2GPI titer in SLE patients being associated with a 6-fold increased risk of secondary APS.

Acknowledgment. This study was supported by CNCSISUEFISCSU, project number PNII - IDEI 2008 code ID_906 and by the Sectoral Operational Programme Human Resources Development (SOP HRD), financed from the European Social Fund and by the Romanian Government under the contract number POSDRU/159/1.5/S/137390.

Declaration of conflicting interests. The authors have no conflicts of interest to declare.

Disclosure. Parts of this research were presented in the $3^{\text {rd }}$ International Congress on Controversies in Rheumatology and Autoimmunity, March 12-14, 2015; Sorrento, Italy. 
Introducere. Sindromul antifosfolipidic (SAFL) este unul dintre cele mai frecvente fenomene autoimune asociate lupusului eritematos sistemic (LES), iar patogeneza celor două entități pare a fi intricată.

Obiective. Investigarea asocierii dintre titrul anticorpilor antifosfolipidici (AAFL) şi prezența SAFL secundar în cadrul LES.

Material şi metode. Au fost incluşi în studiu 65 pacienți ce au îndeplinit criteriile SLICC din 2012. Diagnosticul SAFL a fost susținut conform criteriilor Sydney din 2006. Au fost definite trei grupuri: pacienți cu LES şi SAFL secundar, pacienți cu LES şi AAFL pozitivi însă fără manifestări clinice specifice SAFL şi pacienți cu LES fără AAFL pozitivi sau manifestări clinice ale SAFL. Pacienților le-a fost analizat un panel extins de AAFL: anticorpi tip IgM şi IgG anticardiolipidici ( $a C L)$, anti- $\beta 2$ glicoproteină I (aß2GPI), anti fosfatidiletanolamină $(a P E)$, antifosfatidilserină (aPS) şi antiprotrombină (aPT).

Rezultate. Numai anticorpii aß2GPI (atât IgM cât şi IgG) au avut niveluri semnificativ mai mari la pacienții cu SAFL secundar comparativ cu celelalte două grupuri [mediană (min; max) IgM: 7.0 (0.0-300.0) vs. 1.0 (0.0-28.0) vs. 1.0 (0.0-12.0), IgG: 3.0 (0.0-79.0) vs. 1.0 (0.0-3.0) vs. $1.0(0.0-12.0) \quad(p<0.001$, test Kruskal-Wallis)]. In cadrul analizei regresiei logistice numai anticorpii aß2GPI (IgM şi IgG) au fost identificați ca factor de risc pentru diagnosticul SAFL secundar la pacienții cu LES [OR(95\%CI) 5.9 (2.2-15.7) pentru IgM, respectiv 1.3 (1.1-1.5) pentru IgG]. Titrurile anticorpilor aPS, aPT şi aPE IgG s-au corelat pozitiv cu cel al anticorpilor anti DNAdc pe când concentrația anticorpilor aPS, $a P T$ şi aPE IgM a fost invers corelată cu nivelurile C3 ale complementului.

Concluzii. Anticorpii tip IgG aß2GPI au crescut riscul de aproximativ 6 ori pentru dezvoltarea SAFL secundar. AAFL ce nu sunt incluşi in criteriile de diagnostic nu par să fie asociați cu diagnosticul SAFL secundar la pacienții cu LES. Aceştia sunt însă corelați cu titrul anticorpilor anti DNAdc şi cu nivelurile serice ale componentei $C 3$ a complementului seric.

\author{
Correspondence to: Alina Dima \\ "Colentina" Clinical Hospital, 19-21 Ştefan cel Mare Street, Bucharest, Romania. \\ E-mail: alina_dima@outlook.com
}

\title{
ABBREVIATIONS
}

\author{
Abs - antibodies \\ APLAs - antiphospholipid antibodies \\ APS - antiphospholipid syndrome \\ aPL - antiphospholipid \\ aCL - anticardiolipin \\ a $\beta 2$ GPI - anti- $\beta 2$ glycoprotein I \\ aPE - antiphosphatidylethanolamine \\ aPS - antiphosphatidylserine
}

\author{
aPS/PT - anti-prothrombin in complex with phosphatidylserine \\ aPT - antiprothrombin \\ APS - antiphospholipid syndrome \\ CRP - C-reactive protein \\ DVT - deep vein thrombosis \\ ESR - erythrocyte sedimentation rate \\ LAC - lupus anticoagulant \\ SLE - systemic lupus erythematosus
}

\section{REFERENCES}

1. PETRI M, ORBAi AM, ALARCÓN GS, GORDON C, et al. Derivation and validation of the Systemic Lupus International Collaborating Clinics classification criteria for systemic lupus erythematosus. Arthritis Rheum. 2012; 64(8):2677-86.

2. MIYAKIS S, LOCKSHIN MD, ATSUMI T, BRANCH DW, BREY RL, CERVERA R, et al. International consensus statement on an update of the classification criteria for definite antiphospholipid syndrome (APS). J Thromb Haemost. 2006; 4(2):295-306.

3. PETRI M. Update on anti-phospholipid antibodies in SLE: the Hopkins' Lupus Cohort. Lupus. 2010; 19(4):419-23.

4. WILLIS R, PIERANGELI SS. Pathophysiology of the antiphospholipid antibody syndrome. Auto Immun Highlights. 2011; 24; $2(2): 35-52$ 
5. MCCLAIN MT, ARBUCKLE MR, HEINLEN LD, DENNIS GJ, ROEBUCK J, RUBERTONE MV, et al. The prevalence, onset, and clinical significance of antiphospholipid antibodies prior to diagnosis of systemic lupus erythematosus. Arthritis Rheum. 2004; 50(4):1226-32.

6. GRIKA EP, ZIAKAS PD, ZINTZARAS E, MOUTSOPOULOS HM, VLACHOYIANNOPOULOS PG. Morbidity, mortality, and organ damage in patients with antiphospholipid syndrome. J Rheumatol. 2012; 39(3):516-23.

7. CERVERA R, BUCCIARELLI S, PLASÍN MA, GÓMEZ-PUERTA JA, PLAZA J, PONS-ESTEL G, et al. Catastrophic Antiphospholipid Syndrome (CAPS) Registry Project Group (European Forum on Antiphospholipid Antibodies). Catastrophic antiphospholipid syndrome (CAPS): descriptive analysis of a series of 280 patients from the "CAPS Registry". J Autoimmun. 2009; 32(3-4):240-5.

8. SESTAK A, O’NEIL KM. Familial lupus and antiphospholipid syndrome. Lupus. 2007; 16(8):556-63.

9. RADWAY-BRIGHT EL, RAVIRAJAN CT, ISENBERG DA. The prevalence of antibodies to anionic phospholipids in patients with the primary antiphospholipid syndrome, systemic lupus erythematosus and their relatives and spouses. Rheumatology (Oxford). 2000; 39(4):427-31.

10. RÚA-FIGUEROA I, LÓPEZ-LONGO FJ, CALVO-ALÉN J, GALINDO-IZQUIERDO M, LOZA E, GARCÍA DE YEBENES MJ, et al. Grupo de trabajo en Enfermedades Autoinmunes Sistémicas de la Sociedad Española de Reumatología (EAS-SER); Unidad de Investigación de la Sociedad Española de Reumatología (UI-SER). National registry of patients with systemic lupus erythematosus of the Spanish Society of Rheumatology: objectives and methodology. Reumatol Clin. 2014; 10(1):17-24.

11. UROWITZ MB, GLADMAN DD, IBAÑEZ D, FORTIN PR, BAE SC, GORDON C, et al. Evolution of disease burden over five years in a multicenter inception systemic lupus erythematosus cohort. Arthritis Care Res (Hoboken). 2012; 64(1):132-7.

12. SZODORAY P, TARR T, TUMPEK J, KAPPELMAYER J, LAKOS G, POOR G, et al. Identification of rare antiphospholipid/protein co-factor autoantibodies in patients with systemic lupus erythematosus. Autoimmunity. 2009; 42(6):497-506.

13. ABREU MM, DANOWSKI A, WAHL DG, AMIGO MC, TEKTONIDOU M, PACHECO MS, et al. The relevance of "noncriteria" clinical manifestations of antiphospholipid syndrome: $14^{\text {th }}$ International Congress on Antiphospholipid Antibodies Technical Task Force Report on Antiphospholipid Syndrome Clinical Features. Autoimmun Rev. 2015; 14(5):401-14.

14. SAHIN M, DUZGUN N, TUNC SE, TUTKAK H. Clinical manifestations and antiphosphatidylserine antibodies in patients with systemic lupus erythematosus: is there an association? Clin Rheumatol. 2007; 26(2):154-60.

15. BUTKIEWICZ F, KASZUBA M, BRZEZIŃSKI M, IŻBICKI J, KUBIŚ M, LOPIŃSKI H, et al. Associations between the incidence of antiphosphatidylserine and antiphosphatidylethanolamine antibodies and clinical manifestations of systemic lupus erythematosus. Pol Arch Med Wewn. 2014; 124(11):573-8.

16. MATSUDA J, SAITOH N, GOTOH M, KAWASUGI K, GOHCHI K, TSUKAMOTO M. Phosphatidyl serine-dependent antiprothrombin antibody is exclusive to patients with lupus anticoagulant. Br J Rheumatol. 1996; 35(6):589-91.

17. MATSUDA J, SANAKA T, NISHIZAWA A, GOTOH M, GOHCHI K. Two antiprothrombin antibodies against prothrombin and prothrombin-phosphatidyl serine show partial but not total identity. Blood Coagul Fibrinolysis. 2002; 13(8):697-702.

18. ZUILY S, DE LAAT B, MOHAMED S, KELCHTERMANS H, SHUMS Z, ALBESA R, NORMAN GL, et al. TAC(I)T investigators. Validity of the global anti-phospholipid syndrome score to predict thrombosis: a prospective multicentre cohort study. Rheumatology (Oxford). 2015 Jul 10.

19. REYNAUD Q, LEGA JC, MISMETTI P, CHAPELLE C, WAHL D, CATHÉBRAS P, et al. Risk of venous and arterial thrombosis according to type of antiphospholipid antibodies in adults without systemic lupus erythematosus: a systematic review and meta-analysis. Autoimmun Rev. 2014; 13(6):595-608.

20. BERTOLACCINI ML, MURRU V, SCIASCIA S, SANNA G, KHAMASHTA MA. The clinical value of testing for antibodies to phosphatidylethanolamine (aPE) in patients with systemic lupus erythematosus (SLE). Thromb Res 2012; 130(6):914-8.

21. SANMARCO M, BARDIN N. The contribution of antiphosphatidylethanolamine antibodies in the diagnosis of the antiphospholipid syndrome. Lupus 2012; 21(7):727-8.

22. WAHL DG, GUILLEMIN F, DE MAISTRE E, PERRET C, LECOMPTE T, THIBAUT G. Risk for venous thrombosis related to antiphospholipid antibodies in systemic lupus erythematosus - a meta-analysis. Lupus 1997; 6(5):467-73.

23. ROUBEY RA, PRATT CW, BUYON JP, WINFIELD JB. Lupus anticoagulant activity of autoimmune antiphospho-lipid antibodies is dependent upon beta 2-glycoprotein I. J Clin Invest. 1992; 90(3):1100-4.

24. OOSTING JD, DERKSEN RH, ENTJES HT, BOUMA BN, DE GROOT PG. Lupus anticoagulant activity is frequently dependent on the presence of beta 2-glycoprotein I. Thromb Haemost 1992; 67(5):499-502.

25. DE GROOT PG, URBANUS RT, DERKSEN RH. Pathophysiology of thrombotic APS: where do we stand? Lupus. 2012; 21(7):704-7.

26. BERTOLACCINI ML, GOMEZ S, PAREJA JF, THEODORIDOU A, SANNA G, HUGHES GR, et al. Antiphospholipid antibody tests: spreading the net. Ann Rheum Dis 2005; 64(11):1639-43.

27. KEELING DM, WILSON AJ, MACKIE IJ, ISENBERG DA, MACHIN SJ. Lupus anticoagulant activity of some antiphospholipid antibodies against phospholipid bound beta 2 glycoprotein I. J Clin Pathol. 1993; 46(7):665-7.

28. MCNEIL HP, SIMPSON RJ, CHESTERMAN CN, KRILIS SA. Anti-phospholipid antibodies are directed against a complex antigen that includes a lipid-binding inhibitor of coagulation: beta 2-glycoprotein I (apolipoprotein H). Proc Natl Acad Sci USA.1990; 87(11):4120-4.

29. HARPER BE, WILLS R, PIERANGELI SS. Pathophysiological mechanisms in antiphospholipid syndrome. Int J Clin Rheumtol. 2011; 6(2):157-171.

30. DE LAAT B, DERKSEN RH, URBANUS RT, DE GROOT PG. IgG antibodies that recognize epitope Gly40-Arg43 in domain I of beta 2-glycoprotein I cause LAC, and their presence correlates strongly with thrombosis. Blood 2005; 105:1540-5. 
31. RUFFATTI A, DEL ROSS T, CIPRIAN M, NUZZO M, RAMPUDDA M, BERTERO MT, et al. Risk factors for a first thrombotic event in antiphospholipid antibody carriers. A multicentre, retrospective follow-up study. Ann Rheum Dis. 2009; 68(3):397-9.

32. DANOWSKI A, DE AZEVEDO MN, DE SOUZA PAPI JA, PETRI M. Determinants of risk for venous and arterial thrombosis in primary antiphospholipid syndrome and in antiphospholipid syndrome with systemic lupus erythematosus. J Rheumatol. 2009; 36(6):1195-9.

33. NEVILLE C, RAUCH J, KASSIS J, SOLYMOSS S, JOSEPH L, BELISLE P, et al. Antiphospholipid antibodies predict imminent vascular events independently from other risk factors in a prospective cohort. Thromb Haemost. 2009; 101(1):100-7.

34. BURGOS PI, MCGWIN G JR, REVEILLE JD, VILÁ LM, ALARCÓN GS. Factors predictive of thrombotic events in LUMINA, a multi-ethnic cohort of SLE patients (LXXII). Rheumatology (Oxford). 2010; 49(9):1720-5.

Received July 182015 